\title{
Water-Holding Characteristics of Litter in Meadow Steppes with Different Years of Fencing in Inner Mongolia, China
}

\author{
Jingjie Xie ${ }^{(1)}$ and Derong Su * \\ Research Center for Grassland Ecology and Resources, Beijing Forestry University, No. 35 Tsinghua East Road, \\ Beijing 100083, China; jingjie_xie@bjfu.edu.cn \\ * Correspondence: suderong@bjfu.edu.cn; Tel.: +86-10-62336284
}

Received: 23 June 2020; Accepted: 19 August 2020; Published: 24 August 2020

check for updates

\begin{abstract}
As a main restoration measure to address degraded grasslands, the installation of fences is often accompanied by accumulation of organic litter. This accumulated litter is a layer of physical moisture which intercepts rainfall and may inhibit plant growth and development. One of the important means to judge a reasonable length of time of fencing (the time a fence is present) is through assessing the water-holding mechanism and capacity of the litter. In this study, four meadows in the Chinese Hulunbuir grassland with different years of fencing duration were investigated in order to obtain data on organic community and litter accumulation. A soaking method was used to study water-holding characteristics of the litter and was divided into three parts of stem, leaves and decomposed parts as a means to summarize the water-holding mechanism within the litter. The results showed that: (1) Compared with the light grazing meadows, the diversity and uniformity of communities in meadows of fencing displayed a downward trend, while the accumulation of litter increased. (2) The stems, leaves, and decomposed components of litter in different communities showed a highly positive linear correlation with their maximum water-holding capacity (WHC). This indicates that the stem/leaf mass ratio and decomposition degree of litter are key factors in regulating WHC. (3) Based on this understanding, we established a model based on stem and leaf mass to predict the water-holding potential of litter in real world situations.
\end{abstract}

Keywords: meadow steppe; fence; community characteristic; litter; water-holding capacity (WHC); prediction model

\section{Introduction}

China's arid and semi-arid grasslands account for $40 \%$ of the country's entire area, of which $78 \%$ are located in Northern China [1]. Since 1970, some intense human activities, including overgrazing and reclamation, have led to the degradation of the grasslands [2]. The Chinese Government has implemented a series of grassland protection and restoration policies, such as fence grazing bans and rotation grazing, to improve the diversity, structure and coverage of grassland communities $[3,4]$. Among these, fencing is the most widely used restoration measure. Many studies have shown that fencing can restore grasslands that have been degraded due to overgrazing [5-8]. The gradual increased years of fencing is usually accompanied by the continuous accumulation of litter. Litter is an important component of each grassland ecosystem and plays an important role in maintaining grassland structure, function and community dynamics [9-11]. For fenced grassland, the accumulation of litter has become a highly important ecological process, and the main driving force for sustaining normal ecological function. [12,13]. Scholars believed that rainfall interception of litter is one of the key factors in regulating grassland communities [14,15]. Therefore, researches about the water-holding 
capacity (WHC) of the litter layer can help researchers to explore the ecological significance of litter from the perspective of ecological hydrology.

The interception of rainfall by litter is both beneficial and harmful to the plant community. For example, the litter layer has the function of decreasing soil temperature [14] and reducing the evaporation of soil moisture [16], which is beneficial to the maintenance of soil moisture and has an important impact on the water resources for conservation. As the first functional layer of the ground structure, litter can slow down the impact of rainfall on the soil, carry out secondary interception after the rainfall passes through the canopy [17] and played a role in redistributing rainfall [18]. However, the evaporation of rainwater left on the litter can reduces the infiltration after rainfall [19] and further reduces the soil water content [20]. A study has found that under low-intensity rainfall, the interception rate of litter has an increase of more than $10 \%$ compared with that under normal rainfall [21,22]. During drought periods in semi-arid grasslands, the majority of rainfall is small-intensity, which also makes litter accumulation have a greater rainfall interception effect [23]. Less rainfall entering the soil means less water is available to plants, which makes the inhibition of seed germination $[14,24]$ and reduces community diversity [14]. A recent study demonstrated that as the accumulation of litter increases, the diversity within the community will decrease [25]. Therefore, an estimation model of litter's WHC can help to understand the role litter plays in the process of grassland restoration or degradation.

In order to establish a more accurate model, it is particularly important to understand the internal mechanism that can affect the WHC of litter. Due to the litter with different accumulation usually include different levels of thicknesses, composition and internal structure, scholars usually take the maximum interception of litter as an indicator for judging its WHC. This plays an important role in assessing the effect of hydrology $[19,26]$. Research on the WHC of litter and plant species has been continuously undertaken since 1936 [27]. Taken from the research results of different types of grasslands around the world, it can be observed that grasslands at different altitudes, different accumulated temperatures, and different rainfalls have a high correlation between the WHC of litter and plant species [21,26,28,29]. In China, studies in meadow grassland, plateau grassland and desert grassland have shown similar results [30-33]. Some scholars believed that this is caused by the different composition of species in different communities [19]; however, there is currently limited research to explore its internal mechanism.

Relative to grassland ecosystems, there are many more studies related to the mechanism of litter water-holding capacity within forest ecosystems. For example, Yoshinobu's research found that broad-leaved litter has a higher water-holding capacity than needle-leaved litter [34]. Furthermore, Katalin's research found that the maximum WHC of litter in the forest ecosystem has a limited relation to plant species, and more closely corresponds with leaf type [26]. There is a linear relationship between the minimum interception ratio of broad-leaved litter and leaf area [32]. However, for grassland ecosystems, the leaf shape difference between different plants is minor, the greater level of diversity of grassland communities weakens the difference in litter holding capacity caused by the leaf type among different plants. Different from forest ecosystems, the stem-to-leaf weight ratio of different types of grassland plants is usually larger, making the accumulation rate of leaf litter between communities more varied. In addition, the decomposition rate of grassland litter is higher than that of forest litter [35]. This leads to fine litter occupying a higher proportion of the grass litter layer, increasing its WHC. Therefore, we propose a hypothesis: in the grassland ecosystem, the mass ratio of litter stems, leaves and decomposed small parts plays a key role in regulating the water-holding capacity of the litter layer.

The objectives of our study were to: (1) To obtain data on meadow communities and litter accumulation across different fence years through the use of plant surveys, analyzing the accumulation characteristics of litter in different communities; (2) Obtain the mass and water absorption ratio of stems, leaves and decomposed fine parts of litter in steppes across different fence years through conducing laboratory experiments, and explore the correlation between litter composition and WHC; (3) Summarize the mechanisms that affect WHC of litter, establishing a prediction model for 
water-holding potential. We anticipate that the WHC of the litter has a high correlation with the litter's stem, leaves, and decomposed parts ratio. For different types of grassland communities, the internal mechanisms that can affect the WHC of litter can be unified. Based on this, a general-purpose estimation model of grassland litter's WHC will be established. These results are important for understanding the mechanism of litter's WHC in different communities and predicting the potential WHC of litter in grasslands with different fence years.

\section{Materials and Methods}

\subsection{Experiment Area}

The study area is located in the Huihe National Nature Reserve in Hulunbuir Grassland, a semi-arid area. The geographical coordinates are $48^{\circ} 10^{\prime} 50^{\prime \prime}-48^{\circ} 57^{\prime} 00^{\prime \prime} \mathrm{N}, 118^{\circ} 48^{\prime}-119^{\circ} 45^{\prime} \mathrm{E}$, and the average elevation is $800 \sim 1000 \mathrm{~m}$. The area possesses a mid-temperate continental monsoon climate. The winter is long and cold, the summer is warm and short, the annual average temperature is $-2.4 \sim 2.2^{\circ} \mathrm{C}$, average annual precipitation is 300 350 mm with 70\% of the precipitation concentrated in June to August, and the frost-free period is between 100 120 d. Plant species include Leymus chinensis, Agropyron cristatum, Stipa grandis, Cleistogenes squarrosa, Artemisia frigida, Artemisia capillaris, Potentilla acaulis, Serratula centauroides, and Potentilla bifurca, etc.

\subsection{Plant Investigation}

The plant investigation was conducted during July 2018. The meadows with four different fenced years (SAN: Light grazing; CHA: fenced for three years; GU: fenced for seven years; TE: fenced for ten years) within the Hulunbuir grassland were used as the investigation objects (Figure 1). Five or more $100 \mathrm{~m}$ sample lines are set in parallel in the meadows, and their distance of interval is $50 \mathrm{~m}$. For each sample line, surveys were conducted every $25 \mathrm{~m}$ from one end to the other, and a total of 5 times surveys were performed for each sample line. The plot survey uses the grass-square method: Use a $1 \times 1$ meter's square tool. First tile it on the ground; then count the numbers of various plants in it in turn and cut them off the ground. Up collecting plant statistics, the litter in the square tool is collected, with the litter mass is obtained after air-drying. The mowed plants were killed for one hour in an oven at $105^{\circ} \mathrm{C}$, and then dried in a dryer at $80{ }^{\circ} \mathrm{C}$ for $24 \mathrm{~h}$ to obtain biomass.

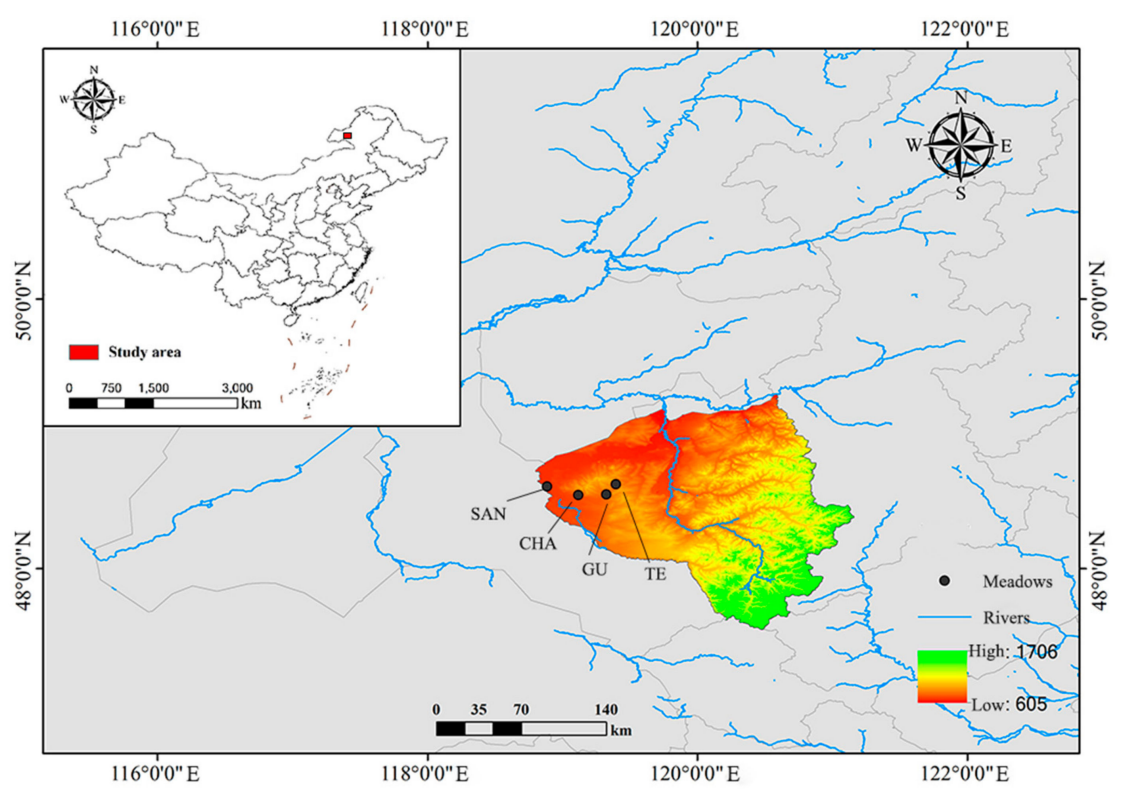

Figure 1. Geographical locations of meadows at four different time of fencing. SAN: light grazing. CHA: fenced for three years. GU: fenced for seven years. TE: fenced for ten years. 


\subsection{Water-Holding Characteristics of Litter}

Nine litter samples were randomly selected from four meadows to be pretreated. The selected litter was classified into three parts: stem, leaves, and decomposed parts. The sum of these three masses is the litter mass, as shown below:

$$
M_{\text {Litter }}=M_{\text {Stem }}+M_{\text {Leaf }}+M_{\text {Decomposed }}
$$

where $M_{\text {Litter: }}$ Litter mass (g); $M_{\text {Stem }}$ : Stem mass (g); $M_{\text {Leaf }}:$ Leaf mass (g); $M_{\text {Decomposed }}$ : Decomposed part mass (g).

The water-holding capacity (WHC) of the litter was measured using the water soaking method. The similar methods were used for the researches about the WHC of forest litter [34] and litter decomposition [36] et al. For each samples of litter, the litter stems, leaves, and decomposed parts were each divided into three equal parts after being weighed; Then, they were each placed in a rounded permeate sieve (Diameter: $20 \mathrm{~cm}$; Only water can pass through) and then been put into a container full with distilled water for $30 \mathrm{~min}$ to make sure each parts of litter be filled with water. After that, the sieves were removed and sit for $15 \mathrm{~min}$ to ensure that no water drops naturally to achieve the maximum WHC. The sum of the maximum WHC of the stem, leaf, and decomposed parts is the WHC of the litter, as shown below:

$$
I_{\text {Litter }}=I_{\text {Stem }}+I_{\text {Leaf }}+I_{\text {Decomposed }}
$$

where $I_{\text {Litter }}$ : Water-holding capacity (WHC) of litter (g); $I_{\text {Stem }}$ : WHC of stem (g); $I_{\text {Leaf }}$ : WHC of leaf (g); $I_{\text {Decomposed }}$ : WHC of decomposed part (g).

The ratio of the WHC of each parts of litter (Stem, Leaf and Decomposed part) to their mass is the water-holding ratio, as shown below:

$$
R_{i}=\frac{I_{i}}{M_{i}} \times 100 \%
$$

where $R$ : Water-holding ratio (\%), I: Water-holding capacity (g), M: Weight (g), $i$ : Litter, Stem, Leaf or Decomposed.

\subsection{Data Analysis}

This research uses SPSS Statistics 20, R language vegan package and Origin 2018 for statistical analysis and plotting of data.

\section{Results}

\subsection{Plant Investigation}

We draw a sparse curve to represent the trend of species richness as the number of samples increases (Figure 2). The results show that the number of samples in the plots SAN, CHA and TE ranges from 25 to 30; Because the plot GU has a larger area than the other three plots. Therefore, in order to better describe the community composition of GU, we conducted a survey of 50 samples. The species richness of each plot varied from 30 to 60, of which the species richness of SAN (light grazing) was the highest, and the species richness of GU (fenced for seven years) was the lowest. The species richness of the four meadows eventually stabilized with the increase in the number of samples, indicating that the sampling depth of each plot was reasonable. 


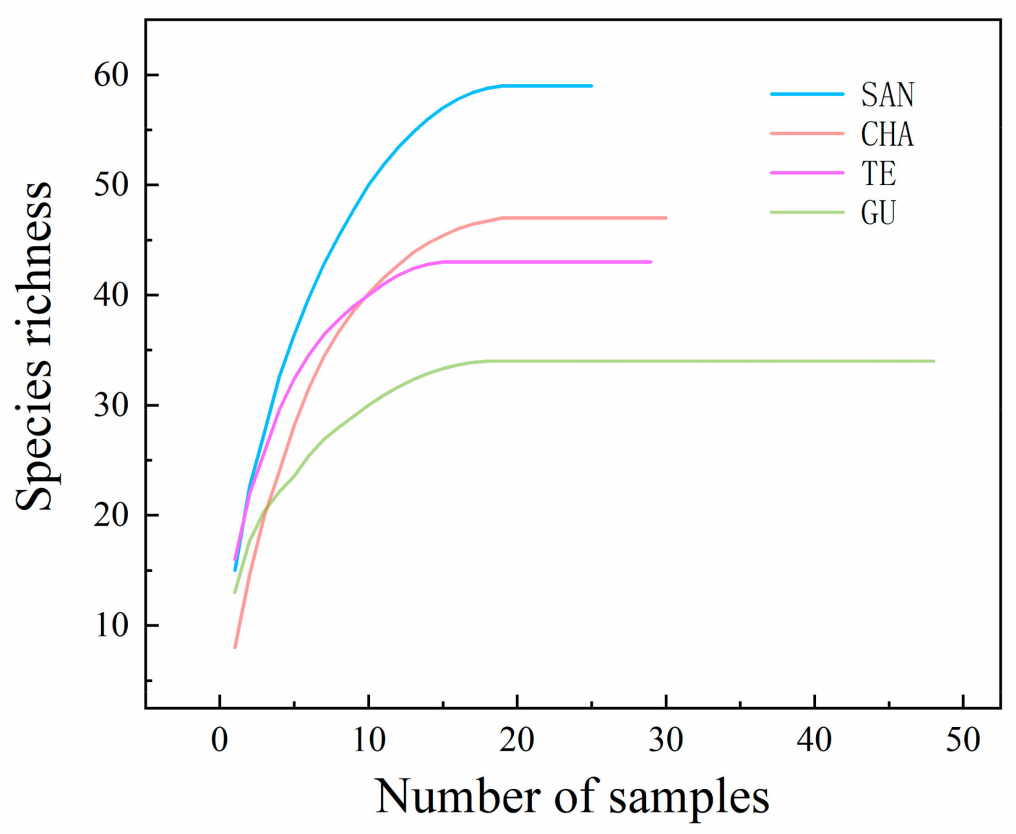

Figure 2. The rarefaction curve of four sampled meadows.

From the plant investigation results (Figure A1), a total of 24 families and 106 plant species were counted across the four plots. Among them, the Poaceae and Asteraceae represented the largest number of species, with 16 plants each. For plant species, Leymus chinensis, Cleistogenes squarrosa, Potentilla acaulis L, Carex duriuscula C.A.Mey, etc., were the plant species that occurred most frequently and have the largest presence in a single square.

It can be seen from Table 1 that the diversity and evenness of various plots have distinctive differences. Compared with fence plots, plot SAN with light grazing have higher diversity and evenness. The diversity of GU and TE of the plots with longer time of fencing is more consistent, and is significantly higher than that of the plot CHA with a three-year fence. Among them, the plot TE with the longest time of fencing show the lowest evenness and community composition is relatively solitary. From the Principal Co-ordinates Analysis (Figure 3), it can be seen that the point distribution of the four meadows is relatively scattered, with the PERMANOVA results showing that $P<0.01$. The diversity among the plots is significant, with the plant species greatly differing between meadows with different time of fencing.

Table 1. Statistical analysis of the utilization patterns and $\alpha$ diversity indicators of the four sampling meadows.

\begin{tabular}{cccccc}
\hline Name & Time of Fencing & Shannon & Simpson & P_Evenness & S_Evenness \\
\hline SAN & Light grazing & $1.681 \pm 0.293^{\mathrm{a}}$ & $4.314 \pm 1.335^{\mathrm{a}}$ & $0.781 \pm 0.086^{\mathrm{a}}$ & $0.497 \pm 0.147^{\mathrm{a}}$ \\
CHA & Three years & $1.074 \pm 0.376^{\mathrm{c}}$ & $2.627 \pm 1.027^{\mathrm{c}}$ & $0.707 \pm 0.202^{\mathrm{b}}$ & $0.574 \pm 0.201^{\mathrm{a}}$ \\
GU & Seven years & $1.324 \pm 0.403^{\mathrm{b}}$ & $3.316 \pm 1.251^{\mathrm{b}}$ & $0.774 \pm 0.129^{\mathrm{a}}$ & $0.578 \pm 0.185^{\mathrm{a}}$ \\
TE & Ten years & $1.368 \pm 0.361^{\mathrm{b}}$ & $3.187 \pm 1.409^{\mathrm{bc}}$ & $0.64 \pm 0.136^{\mathrm{c}}$ & $0.377 \pm 0.173^{\mathrm{b}}$ \\
\hline & & & & $p<0.05$ Duncan
\end{tabular}

Notes. Shannon: Shannon Wiener Index; Simpson: Simpson index; P_evenness: Pielou evenness index; S_evenness: Simpson evenness index; ${ }^{a}, b, c$ : The result of significance test of difference (The residuals of each group of data conform to the normal distribution). 


\section{bray_curtis PCoA}

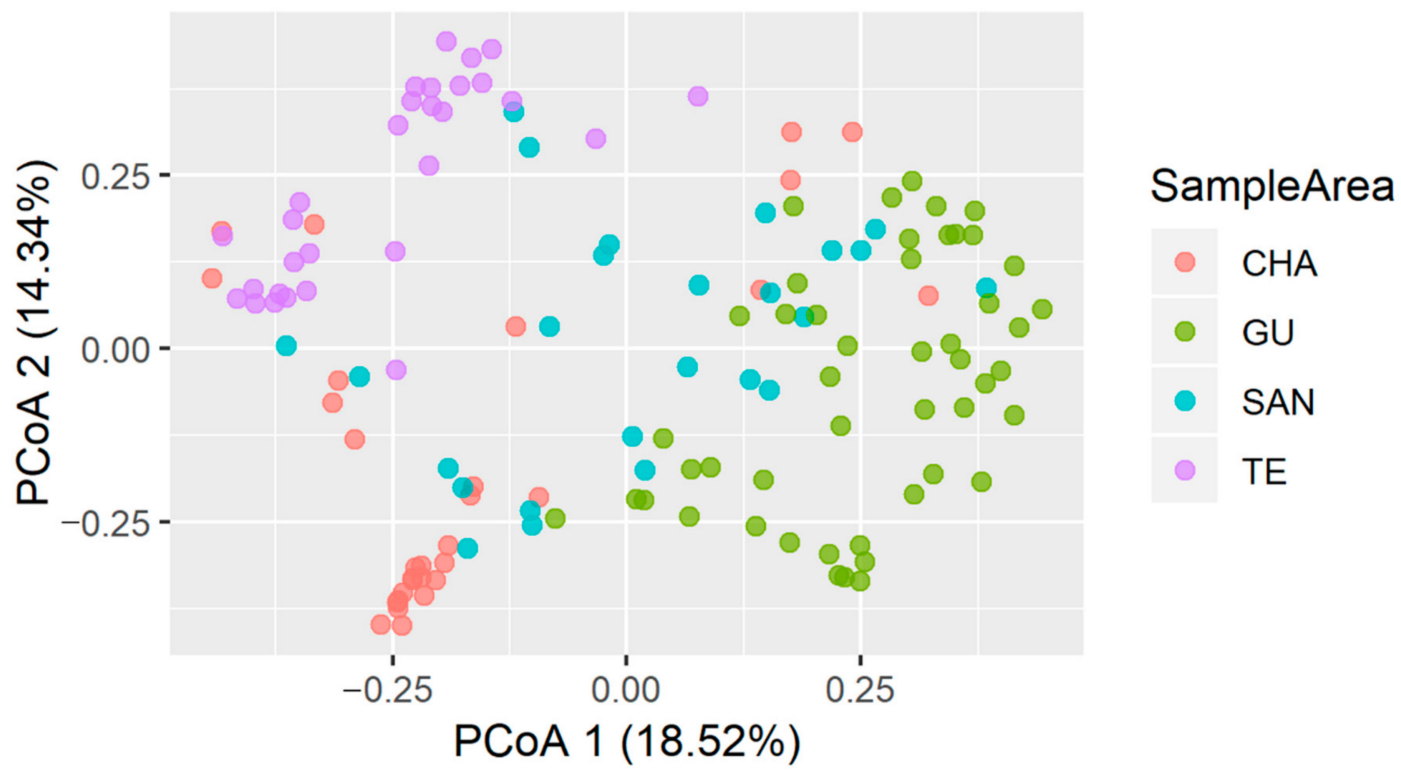

Figure 3. Principal Co-ordinates Analysis (PCoA) of four sampled meadows. The PERMANOVA results show that $P<0.01$.

\subsection{Litter Characteristics}

The average litter accumulation across the four meadows vary depending on factors such as plant species and time of fencing. From Figure 4a it can be seen that the TE litter mass fenced for ten years is the highest, with an average value of $320 \mathrm{~g} / \mathrm{m}^{2}$. The litter mass measurements in each meadow were all different. The lowest value was only $80 \mathrm{~g} / \mathrm{m}^{2}$ and the highest was $505 \mathrm{~g} / \mathrm{m}^{2}$. The litter accumulation of SAN (light grazing) was the lowest, with an average of only $40 \mathrm{~g} / \mathrm{m}^{2}$. Moreover, the litter accumulation difference in the sample plot SAN was also the smallest, with a minimum value of $0 \mathrm{~g} / \mathrm{m}^{2}$. After fitting the litter mass of all the litter samples in four meadows to their biomass (Figure $4 \mathrm{~b}$, the outliers had been excluded), it can be found that the two showed an exponential correlation: $y=a+b e^{c x}, a=5.52 \pm 34.08, b=17.54 \pm 14.62, c=0.01 \pm 0.003, R^{2}=0.63$, and $P<0.01$. The litter mass increased with the aboveground biomass, and its increase rate gradually increased. This result is similar to the change of litter accumulation in meadows of different years of fencing (Figure 4a).

\subsection{Water-Holding Characteristics of Litter}

Through statistical analysis of the water-holding ratio for each part of the litter, it can be observed (Figure 5a) that the stem, leaf, and decomposed parts' water-holding ratio of the litter are at $170 \%$, $260 \%$, and $330 \%$, respectively. Among them, the water-holding ratio of the decomposed part is the most unstable, with the difference between the upper and lower limits reaches $150 \%$. The water-holding ratio of the other two litter parts is relatively stable. The water-holding ratio of the litter is more consistent with that of the leaves, and there is no significant difference between the two.

For the three parts of litter (stem, leaf and decomposed part) from four different pastures, their mass and WHC were linearly fitted. For the three fitting results obtained, the residuals of their dependent variables all conform to the normal distribution, and $P<0.05$. As showed in the Figure $5 \mathrm{~b}$, even if the time of fencing, plant species, and litter accumulation of each meadow are different, the fitting results of the litter's three parts reflect a positive correlation linear relationship. The $\mathrm{R}^{2}$ of stem, leaf and decomposed parts were $0.966,0.966$, and 0.838 . This indicated that the WHC of each part of the litter is highly (and not only) related to its own mass. 


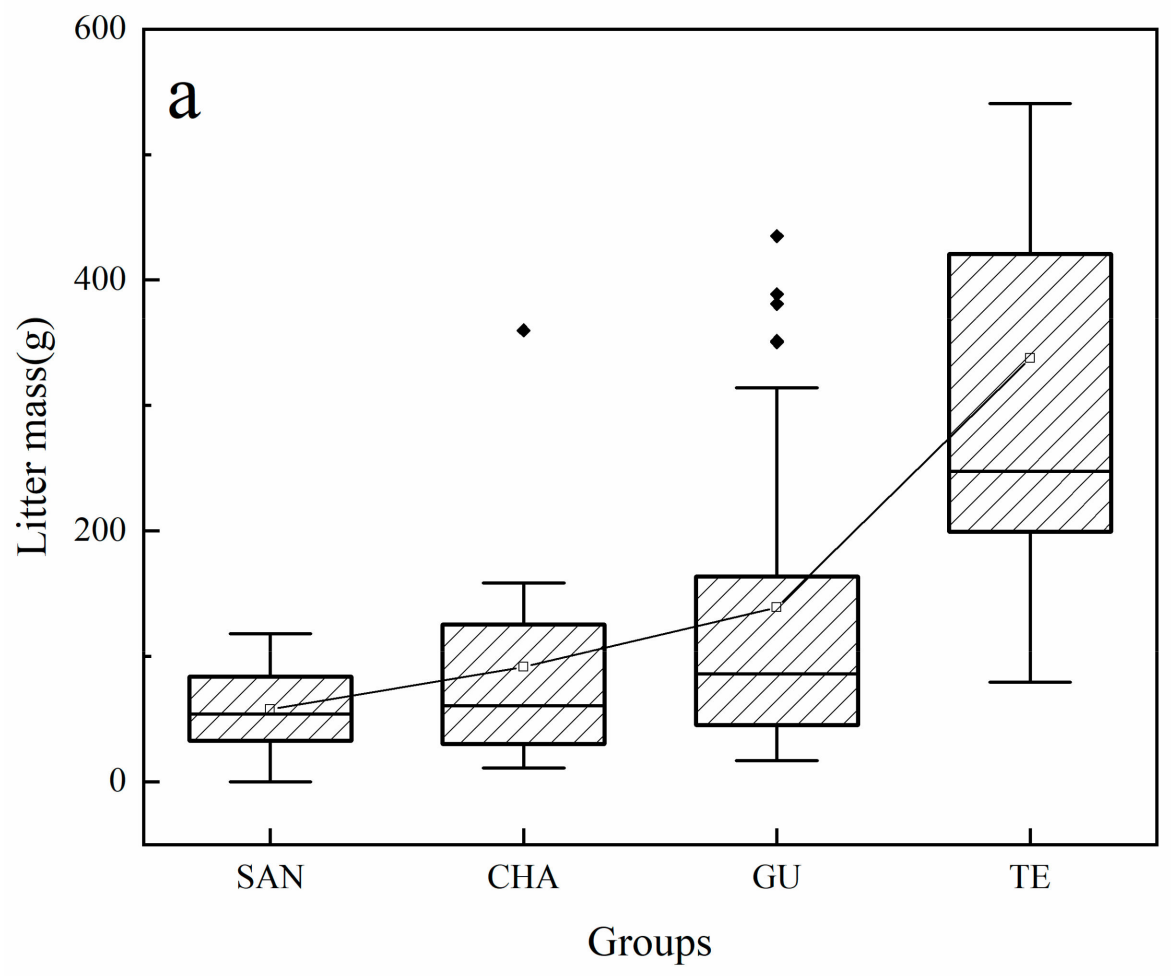

(a)

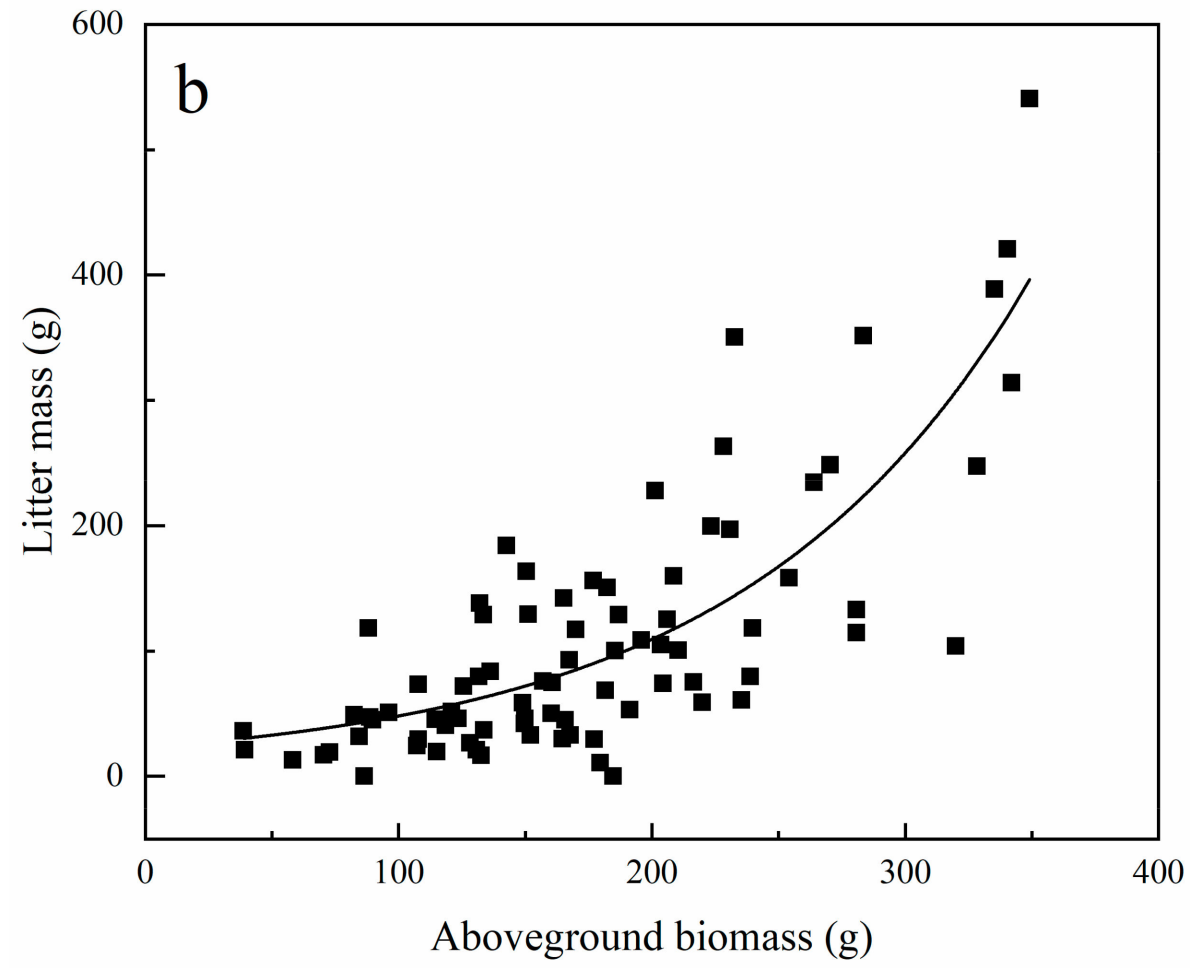

(b)

Figure 4. (a) Boxplot of the various sample squares' litter accumulation in the four sample meadows. (b) Nonlinear fitting of biomass and litter mass of all sample square in four sampled meadows. $y=a+b e^{c x}, P<0.01$. 


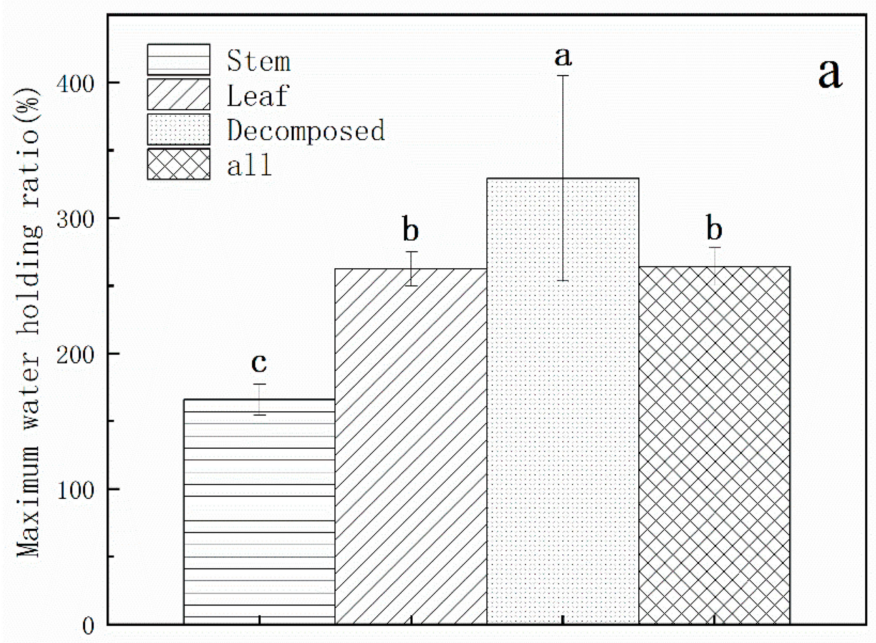

(a)

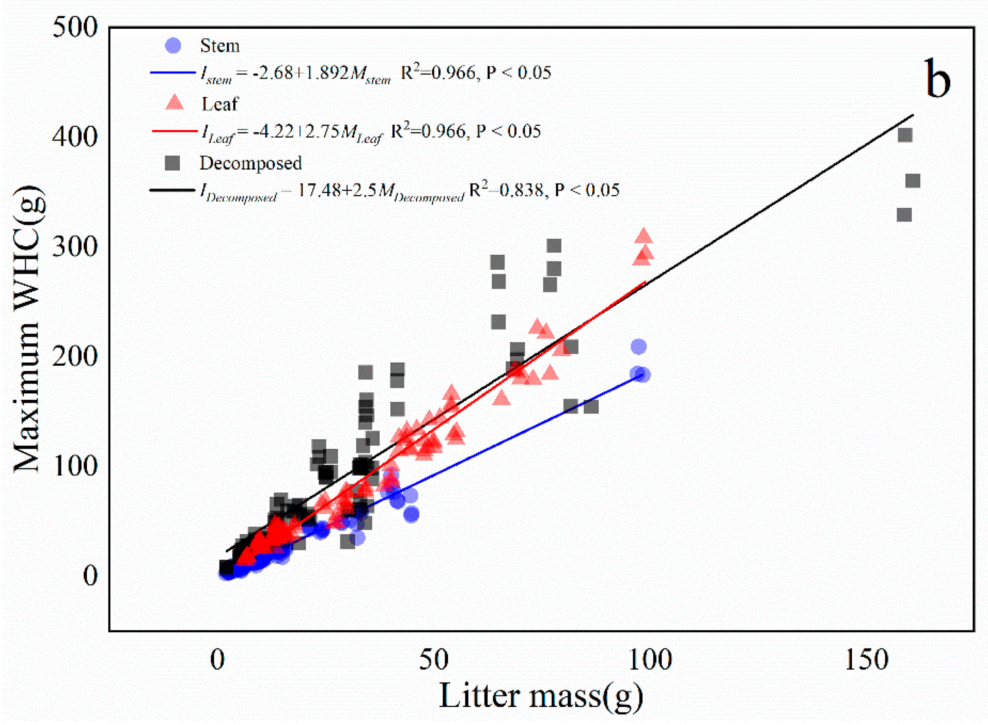

(b)

Figure 5. (a) The water-holding ratio of stem, leaf and decomposed parts of litter. (b) Linear fitting of the mass of stem, leaf and decomposed with its water-holding capacity (WHC) in all samples.

\subsection{Model of Litter's Water-Holding Capacity}

The previous section of this research had found that the litter's water-holding ratio is similar as that of the litter's leaf (Figure 5a). Therefore, we use the mass of the litter leaf as a benchmark to establish the water-holding model of the litter. One independent variable (leaf mass), two independent variables (leaf and stem mass) and three independent variables (leaf, stem and decomposed part mass) were used to linearly fit with the water-holding capacity (WHC) of the litter. The residuals of their dependent variables all conform to the normal distribution, and $P<0.05$. The three models of theoretical water-holding capacity of litter are as follows:

$$
\begin{gathered}
I_{\text {Litter }}=-14.75+6.89 M_{\text {Leaf }} R^{2}=0.897, P<0.05 \\
I_{\text {Litter }}=12.66+3.99\left(M_{\text {Leaf }}+M_{\text {Stem }}\right) R^{2}=0.884, P<0.05 \\
I_{\text {Litter }}=-0.76+2.62\left(M_{\text {Leaf }}+M_{\text {Stem }}+M_{\text {Decomposed }}\right) R^{2}=0.959, P<0.05
\end{gathered}
$$


where $I_{\text {Litter }}$ : Water-holding capacity of litter (g); $M_{\text {Litter }}$ : Litter mass (g); $M_{\text {Stem }}$ : Stem mass (g); $M_{\text {Leaf }}$ : Leaf mass (g); $M_{\text {Decomposed }}$ : Decomposed part mass (g).

The results can be seen in Figure 6a, the $\mathrm{R}^{2}$ from the three models are 0.897, 0.884, and 0.959, all demonstrated high levels of accuracy. Among them, the model (Equation (6)) using the leaf, stem and decomposed part mass as the independent variable is the most accurate. It can be seen from the comparison of the theoretical and actual values of the WHC of the three models (Figure 6b) that there is no significant difference between the three, and they can all be put into production practice.

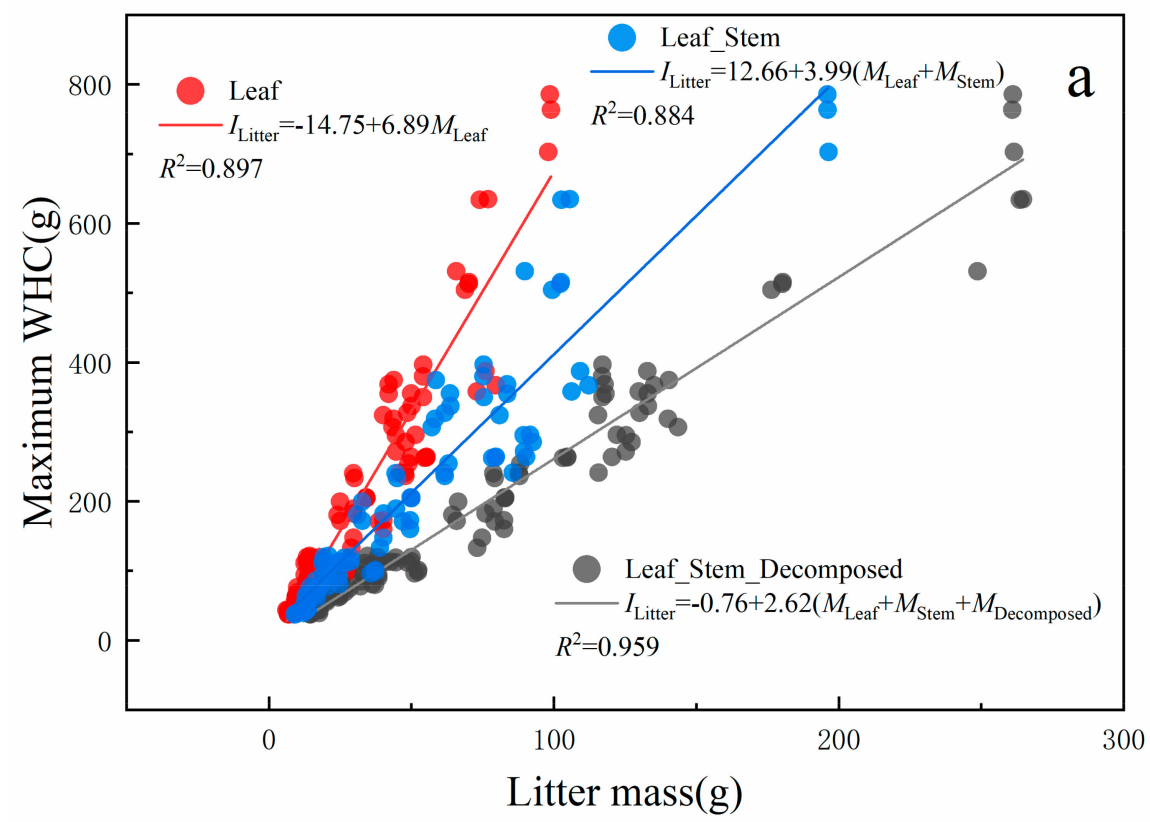

(a)

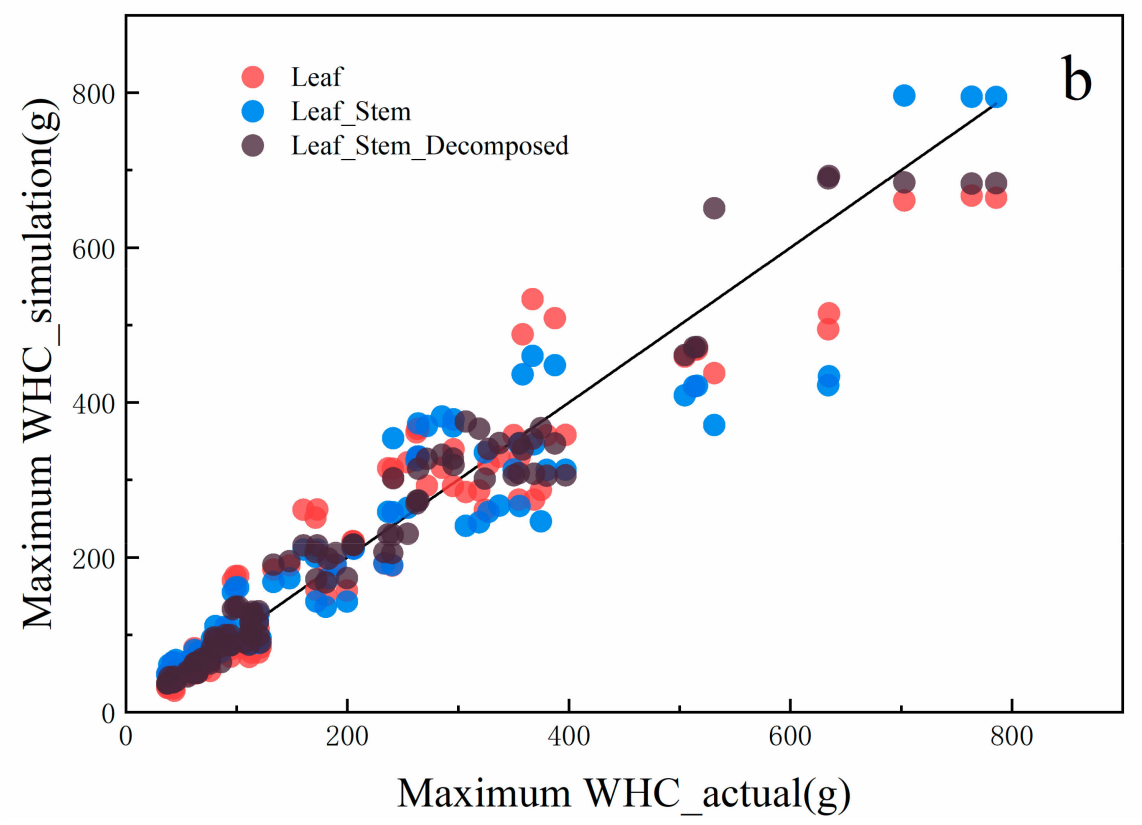

(b)

Figure 6. (a) Three different linear models of water-holding capacity (WHC). (b) The comparison between the observed value and the estimated value of the three models of WHC. 


\section{Discussions}

\subsection{Plant Investigation}

In this study, the alpha diversity of communities with different years of fencing revealed a significant difference. It can be seen from Table 1 that compared with a lightly grazed meadow, the diversity and evenness of the fenced meadow steppes are significantly reduced, consistent with research results [5,6,37-40]. Among these, the evenness tends to gradually decrease with the increase of the years of fencing. Competitive exclusion of competing species that cannot coexist in the same ecological niche for a long period is the main reason for diversity and evenness to decrease after fencing [41]. In meadows that have lost grazing pressure after being fenced, the impact of livestock palatability preferences on interspecies competition in communities essentially no longer exists [42]. This amplifies the competitive advantages of some dominant species and accelerates community succession. With the increase of time of fencing, some rhizome grasses with high water tolerance have multiplied rapidly [43]. However, for some seed-producing cluster grasses, their seeds gradually fail to obtain sufficient sunlight and moisture for germination, and some seeds even cannot reach the soil surface due to the litter. These factors have contributed to a decline in species diversity within community in line with the increase of the years of fencing. A study in northern Mongolia found that for long-term fenced meadows [44], the single-layer structure of the tall grass community was mostly displayed within the fence due to the lack of photosynthesis of the underlying plants, while moderately grazed meadows outside the fence were mostly double-layered structures. This is precisely because the height, shape, regeneration ability, palatability, etc., of plants impacting on its own competitive advantage [45]. In addition, changes in seed germination conditions [24], direct physical interference [16], and encouragement of pathogens [46] will all affect the development of the community. Following a decrease in disturbances within the grassland, there has been a clear trend towards the expanding competitive advantage of dominant plants. After long-term fencing, the richness index, Shannon Wiener index, and evenness index all decreased, resulting in the community becoming ever more singular and vulnerable $[39,40]$.

We performed PCoA analysis of plant species differences ( $\beta$ diversity) in four different meadows (Figure 4). The results of the point distribution across the four meadows were relatively scattered, with the $\mathrm{P}<0.01$ of PERMANOVA indicated that the plant diversity and species were significantly different between meadows of different fenced years. The Poaceae plants, Asteraceae plants, Fabaceae plants, and Rosaceae plants as the dominant species in the local steppe (Figure A1). The original community composition [47], soil conditions [48], and the degree of human influence [41] are among the main reasons that lead to different species composition within different meadows. For example, grazing often results in weed species dominating in arid regions [44]. In temperate grasslands, plants with tillering advantages, such as Leymus chinensis, gain a greater advantage under grazing conditions [49]. In addition, time of fencing [39], annual rainfall [50], and light conditions [41] are all reasons for the large differences in plant communities in different meadows with different fence years.

\subsection{Characteristics of Litter Accumulation}

This study found that the amount of litter accumulation and their range increased with the time of fencing (Figure 4a). This is because the increase in time of fencing is usually accompanied by an increase in aboveground biomass [51]. The higher aboveground biomass will lead to more litter accumulation. In addition, the longer time of fencing highlights the choice of dominant species in the community by microtopography and light competition [41,48], which led to different succession directions for different communities, and caused fragmentation of the landscape. The litter accumulation capacity of different community types is also different, which leads to large variations in litter accumulation in plot TE fenced for ten years. However, for grasslands with short fenced years, we have yet to see an emergence of dominant species, and the composition of the communities remains relatively homogeneous. This leads to the difference in litter accumulation among different communities relatively small. 
It can be seen from Figure $4 \mathrm{~b}$ that the litter accumulation and the aboveground biomass have an exponential correlation. This means that, since the increase in time of fencing is usually accompanied by an increase in aboveground biomass [51], the accumulation of litter and aboveground biomass may also have an exponential correlation. Compared with the other three plots, the litter accumulation of grassland in the TE (fenced for 10 years) increased significantly, with an average value of $320 \mathrm{~g} / \mathrm{m}^{2}$. This is because with the time of fencing exceeding ten years, some rhizome-type high-biomass grass species, such as Leymus chinensis, have expanded and multiplied in large numbers, gradually becoming the clear dominant species within the community [52]. The higher aboveground biomass increased the growth rate of litter accumulation, resulting in a relatively high accumulation of litter in the TE. In the process of fencing, the increasing rate of litter accumulation may mean that there is a threshold for time of fencing. Once the time of fencing exceeds the threshold, litter will quickly accumulate and cause water stress to the community. However, the time threshold of communities with different types may be different, which is worthy of further study.

\subsection{Water-Holding Characteristics of Litter}

Although the plant types of the four meadows in this study are also significantly different, there is no difference in the water-holding ratio of each part of their litter. It can be seen (Figure $5 b$ ) that the fitting results of the three parts respectively show a highly positive correlation linear relationship, with the $\mathrm{R}^{2}$ of the three are $0.966,0.966$, and $0.838, P<0.05$. This shows that for grassland communities, the stem-leaf mass ratio and decomposition degree in the litter may be the key influencing factors that affect the WHC of the litter layer. The difference in the weight and proportion of the three parts of litter is the internal mechanism that can regulates the WHC of litter on the four meadows in this study. It can also partly explain the large differences in the WHC of litter from different plants and communities in other studies [19,21,27-29,53]. A study on forest ecosystems identified that the WHC of litter of broad-leaved and coniferous tree species is related to leaf type [34]. However, for grassland litter, plant leaves are mostly slender, with the leaf shape having limited effect on the structure of the litter layer. However, the stem-to-leaf mass ratio of different types of plants is often significant. A litter layer with a large proportion of leaf mass tends to exhibit a denser structure than that of a litter layer with a relatively small leaf mass, capable of maintaining more interstitial water. In addition, the decomposition of the litter layer with more litter fines have accumulated can increase the compactness of the litter layer structure and maintain more water, which affects the WHC of the overall litter layer. The stem-leaf ratio and decomposition degree of the plant community together affect the WHC of the litter layer through the WHC of each litter parts and their ability to adjust the structure of the litter layer.

It can be found from Figure 5a that the water-holding ratio of stems $(170 \%)$, leaves $(260 \%)$, and decomposed parts $(330 \%)$ have significant differences. The difference in water absorption capacity of stems and leaves is one of the reasons for this phenomenon. These stems are mostly xylem with thick fibers, with the structure between cells is relatively stable, which is difficult for water absorption, although the internal tubular structure is rich. The fibers in the leaves are relatively soft, and there are more damaged cells across the surface layer, which means water easily enters inside the litter leaves through the water potential difference. On the other hand, the relative structural difference between the three litter parts is also one of the reasons for the significant differences in their water-holding ratios. The particle size of the litter stems, leaves, and decomposed parts gradually decreased, which made their structures also exhibit a change from loose to dense. The tighter the structure, the more interstitial water can be maintained, as such the WHC of litter tends to increase as the litter particles increase [19]. Therefore, the WHC of litter is greatly affected by the mass ratio of stems and leaves and the degree of decomposition. Due to the different degrees of litter decomposition, and the difference particle size distribution within the litter, the water-holding ratio of the litter in different communities is highly varied. In addition, we found that the water-holding ratio of the litter was more consistent with that of the litter leaves, which was $260 \%$, with no significant difference. This is because the mass and structural volume of the litter leaves occupy a large proportion in across the entire litter layer, meaning 
that it can dominate the overall water-holding ratio. Then, the poor water-holding capacity of the stem and the strong water-holding capacity of the decomposed parts offset each other, so that the overall water-holding ratio of the litter is biased to the leaves with medium water-holding capacity.

\subsection{Water-Holding Model of Litter}

We have established three litter WHC models that can be used in production practice. It can be seen from Equations (4)-(6) that the accuracy of the three is 0.897, 0.884, and 0.959, respectively, and the model with the three parts of litter as the independent variable has the highest correlation (Equation (6)). Although the Equation (6) is the most accurate model, it is not applicable to actual operation. Because a large part of the decomposed part of the litter accumulates on the upper layer of the soil surface and is mixed with the soil. If people want to avoid the errors caused by the soil, they need to sieve the soil with a soil sieve which makes the work process more complicated. For the Equations (4) and (5), compared with the actual values, their degree of dispersion is larger only in the range of WHC greater than $400 \mathrm{~g}$, but smaller in other ranges, which showed a relatively consistent trend (Figure 6b). However, for Equation (4), it is necessary to separate the leaves and stems in actual operation, which will also reduce the operation efficiency to a small extent. Therefore, we recommend Equation (5) (with stem and leaf mass as the independent variable) as a suitable model for the calculation of litter WHC. It can be put into practical production more efficiently. Of course, if people need to more accurately estimate the WHC of litter and don't care about the complicated process, Equation (6) is more appropriate.

The models in this research can more accurately estimate the maximum WHC of litter of the same type of meadows in the Hulunbuir grassland. This helps to judge the rationality of the years of fencing for some meadows from the perspective of water use. At the same time, this model can provide some effective support when the local government formulates an enclosure policy for ecological restoration. For some studies on litter and canopy interception [12,17,19,22,23,29,30,34], as well as studies on water flux at the vegetation-soil interface [14,19,48,53], these models can be used as an auxiliary method to predict the maximum WHC of litter. So as to make more reasonable scientific assumptions. In addition, litter has always been an indispensable target in the research on nutrient deposition $[10,19,36,41,50]$. This study also found that the degree of decomposition of litter will have a significant impact on its maximum WHC. Thus, Equation (6) can better estimate the maximum WHC of meadow community litter with different decomposition degrees, which helps to explain some results more reasonably.

\section{Conclusions}

The difference in time of fencing affects the types of plant species and structure of a meadow community. Compared with light grazing meadows, the diversity and uniformity of communities in fencing meadows showed a downward trend, and the accumulation of litter increased with the time of fencing. Although the communities of the meadows with different years of fencing are different, their stems, leaves, and decomposed components of litter displayed a highly positive linear correlation with their maximum WHC, with the maximum water-holding ratios of stems, leaves, and decomposed parts being recorded at $170 \%, 260 \%$, and $330 \%$. This indicates that the stem/leaf mass ratio and decomposition degree of litter are a key factor in regulating WHC. The overall water-holding ratio of litter was recorded as being approximately equal to that of the litter leaves. Based on these observations we established three litter WHC models based on the mass of litter leaves. Among them, a linear model fitted with litter stem and leaf mass $\left(I_{\text {Litter }}=12.66+3.99\left(M_{\text {Leaf }}+M_{\text {Stem }}\right) R^{2}=0.884\right)$ as the independent variable is the most efficient for practical application in the prediction of litter water-holding potential. The model fitted with litter stem, leaf and decomposed part's mass $\left(I_{\text {Litter }}=-0.76+2.62\left(M_{\text {Leaf }}+M_{\text {Stem }}+M_{\text {Decomposed }}\right) R^{2}=0.959\right)$ as the independent variable is most accurate. The results of this study are an important step towards more effective grassland management practices. 
Author Contributions: Conceptualization, J.X. and D.S.; Data curation, J.X.; Formal analysis, J.X.; Funding acquisition, D.S.; Investigation, J.X.; Methodology, J.X. and D.S.; Project administration, D.S.; Resources, D.S.; Software, J.X.; Supervision, D.S.; Writing-original draft, J.X. All authors have read and agreed to the published version of the manuscript.

Funding: This work was funded by Specific Research on National Key R\&D Plan (2017YFC0504004) and Public Service of Environmental Protection in China (No. 201509040).

Acknowledgments: We thank staffs from Chinese Research Academy of Environmental Sciences, and Huihe National Nature Reserve for offering help.

Conflicts of Interest: The authors declared that they have no conflicts of interest to this work.

\section{Appendix A}

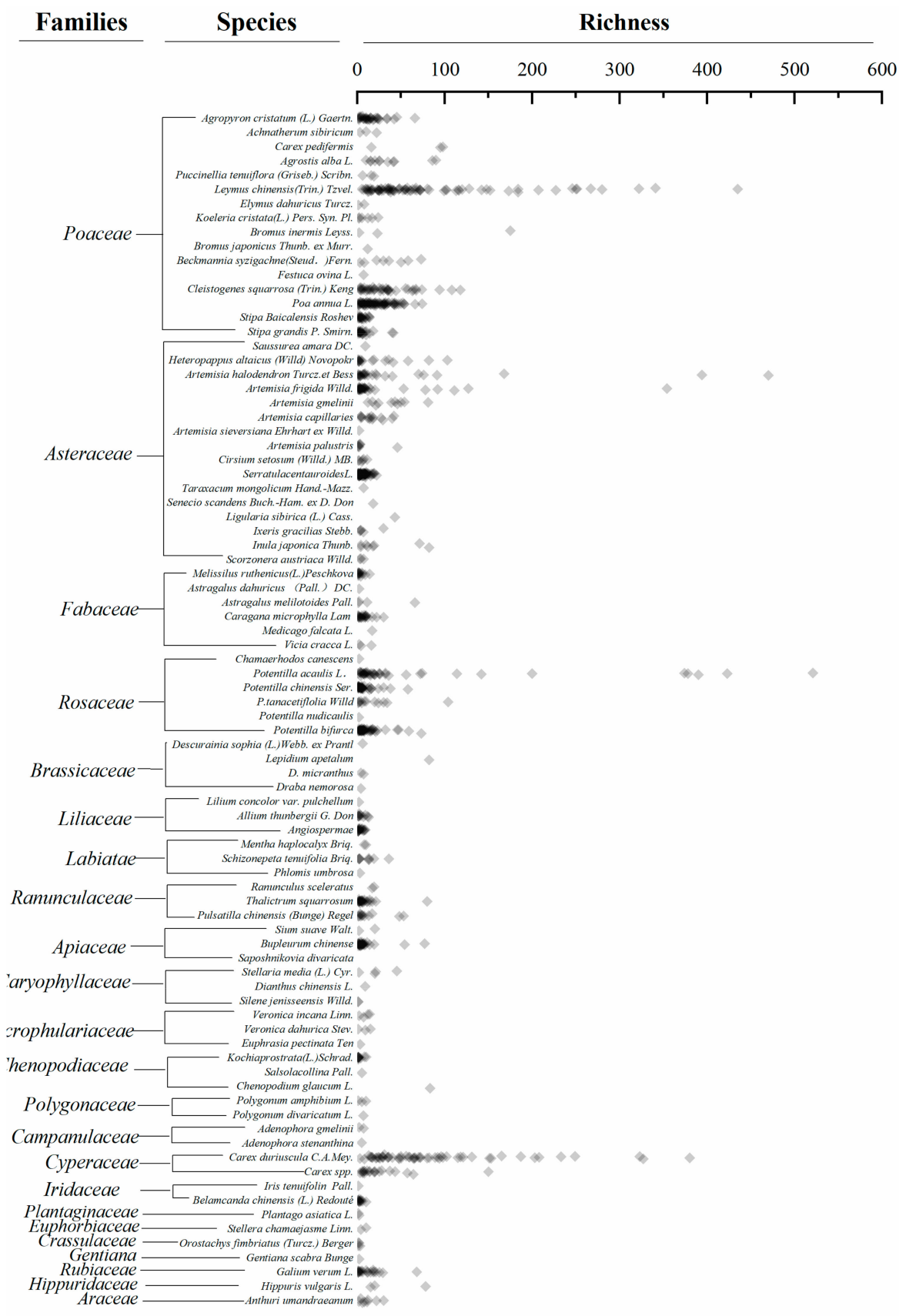

Figure A1. A summary of the total plant families and species of the sampled meadows. 


\section{References}

1. Sun, H.L. Ecosystem of China; Science Press: Beijing, China, 2005; pp. 150-201.

2. Jiang, G.; Han, X.; Wu, J. Restoration and management of the Inner Mongolia grassland require a sustainable strategy. AMBIO J. Hum. Environ. 2006, 35, 269-270. [CrossRef]

3. Jia, X.N.; Cheng, J.M.; Wan, H.E. Effects of Enclosure on the Community Characteristics of Stipa bungeana Grassland in Yunwu Mountain. Acta Agrestia Sin. 2008, 3, 272-277. Available online: http://en.cnki.com.cn/ Article_en/CJFDTOTAL-CDXU200803013.htm (accessed on 19 August 2020).

4. Lv, S.H.; Feng, C.S.; Gao, J.X.; Lu, X.S. Study on Enclosing Effects and Biodiversity Variation of Desertification Grassland in Hulunbeir Steppe. Acta Agrestia Sin. 2008, 5, 442-447. Available online: http:/en.cnki.com.cn/ Article_en/CJFDTOTAL-CDXU200805004.htm (accessed on 19 August 2020).

5. Jing, Z.; Cheng, J.; Chen, A. Assessment of vegetative ecological characteristics and the succession process during three decades of grazing exclusion in a continental steppe grassland. Ecol. Eng. 2013, 57, 162-169. [CrossRef]

6. Cheng, J.; Gao, Y.; Jing, Z.; Jin, J.; Jimin, J.Z.C. Restoration and Utilization Mechanism of Degraded Grassland in the Semi-arid Region of Loess Plateau. Sci. Sin. Vitae 2014, 44, 267-279. [CrossRef]

7. Liu, J.; Wu, J.; Su, H.; Gao, Z.; Wu, Z. Effects of grazing exclusion in Xilin Gol grassland differ between regions. Ecol. Eng. 2017, 99, 271-281. [CrossRef]

8. Wu, G.-L.; Du, G.; Liu, Z.-H.; Thirgood, S. Effect of fencing and grazing on a Kobresia-dominated meadow in the Qinghai-Tibetan Plateau. Plant Soil 2008, 319, 115-126. [CrossRef]

9. Okin, G.S. The contribution of brown vegetation to vegetation dynamics. Ecology 2010, 91, 743-755. [CrossRef]

10. Geng, Y.B.; Shi, J.J. Influencing Factors of Grassland Litter Decomposition and Nutrient Release and Accumulation. Prog. Geogr. 2012, 5, 655-663. Available online: http://en.cnki.com.cn/Article_en/CJFDTOTALDLKJ201205018.htm (accessed on 19 August 2020).

11. Liu, Q.; Peng, S.L. Plant Litter Ecology; Science Press: Beijing, China, 2010; pp. 23-54.

12. Amatangelo, K.L.; Dukes, J.S.; Field, C.B. Responses of a California annual grassland to litter manipulation. J. Veg. Sci. 2008, 19, 605-612. [CrossRef]

13. Patrick, L.B.; Fraser, L.H.; Kershner, M.W. Large-scale manipulation of plant litter and fertilizer in a managed successional temperate grassland. Plant Ecology 2008, 197, 183-195. [CrossRef]

14. Deutsch, E.; Bork, E.; Willms, W.D. Soil moisture and plant growth responses to litter and defoliation impacts in Parkland grasslands. Agric. Ecosyst. Environ. 2010, 135, 1-9. [CrossRef]

15. Loydi, A.; Eckstein, R.L.; Otte, A.; Donath, T.W. Effects of litter on seedling establishment in natural and semi-natural grasslands: A meta-analysis. J. Ecol. 2012, 101, 454-464. [CrossRef]

16. Facelli, J.M.; Pickett, S.T.A. Plant Litter: Light Interception and Effects on an Old-Field Plant Community. Ecology 1991, 72, 1024-1031. [CrossRef]

17. Gerrits, A.M.J.; Pfister, L.; Savenije, H.H. Spatial and temporal variability of canopy and forest floor interception in a beech forest. Hydrol. Process. 2010, 24, 3011-3025. [CrossRef]

18. Jensen, K.; Gutekunst, K. Effects of litter on establishment of grassland plant species: The role of seed size and successional status. Basic Appl. Ecol. 2003, 4, 579-587. [CrossRef]

19. Naeth, M.A.; Bailey, A.W.; Chanasyk, D.S.; Pluth, D.J. Water Holding Capacity of Litter and Soil Organic Matter in Mixed Prairie and Fescue Grassland Ecosystems of Alberta. J. Range Manag. 1991, 44, 13-17. [CrossRef]

20. Knapp, A.K.; Seastedt, T.R. Detritus Accumulation Limits Productivity of Tallgrass Prairie. Bioscience 1986, 36, 662-668. [CrossRef]

21. Corbett, E.S.; Crouse, R.P. Rainfall Interception by Annual Grass and Chaparral: Losses Compared; Forest Service Research Paper PSW-48; US Department of Agriculture: Berkeley, CA, USA, 1968; pp. 1-11.

22. Couturier, D.E.; Ripley, E.A. Rainfall Interception in Mixed Grass Prairie. Can. J. Plant Sci. 1973, 53, 659-663. [CrossRef]

23. Hou, D.; He, W.-M.; Liu, C.; Qiao, X.; Guo, K. Litter accumulation alters the abiotic environment and drives community successional changes in two fenced grasslands in Inner Mongolia. Ecol. Evol. 2019, 9, 9214-9224. [CrossRef]

24. Carson, W.P.; Peterson, C.J. The role of litter in an old-field community: Impact of litter quantity in different seasons on plant species richness and abundance. Oecologia 1990, 85, 8-13. [CrossRef] [PubMed] 
25. Lamb, E.G. Direct and Indirect Control of Grassland Community Structure by Litter, Resources, and Biomass. Ecology 2008, 89, 216-225. [CrossRef] [PubMed]

26. Zagyvai-Kiss, K.A.; Kalicz, P.; Szilagyi, J.; Gribovszki, Z. On the specific water holding capacity of litter for three forest ecosystems in the eastern foothills of the Alps. Agric. Meteorol. 2019, 278, 1-8. [CrossRef]

27. Flory, E.L. Comparison of the Environment and Some Physiological Responses of Prairie Vegetation and Cultivated Maize. Ecology 1936, 17, 67-103. [CrossRef]

28. Weaver, J.E.; Rowland, N.W. Effects of Excessive Natural Mulch on Development, Yield, and Structure of Native Grassland. Int. J. Plant Sci. 1952, 114, 1-19. [CrossRef]

29. Burgy, R.H.; Pomeroy, C.R. Interception losses in grassy vegetation. Trans. Am. Geophys. Union 1958, 39, 1095-1100. [CrossRef]

30. Li, X.B.; Chen, L.; Tian, Z.; Wang, X.Y.; Liu, B.R.; Liu, R.; Xie, Y.Z. Water Holding Capacity and Capita Storage of Plant Community Litter in Representative Desert Steppe. J. Soil Water Conserv. 2011, 6, 144-147. Available online: http://en.cnki.com.cn/Article_en/CJFDTotal-TRQS201106032.htm (accessed on 19 August 2020).

31. Shi, S.; Guo, J.X. Ecohydrological functions of litter in three main plan tcommunities on Songnen grassland. Chin. J. Appl. Ecol. 2007, 8, 1722-1726. Available online: http://www.cjae.net/CN/Y2007/V18/I08/1722 (accessed on 19 August 2020).

32. Zhang, Y.; Li, P.; Liu, X.J.; Ren, Z.P.; Ma, T.T.; Zhao, B.H.; Xu, G.C. Water Holding Capacity of Litter with Different Vegetation Types in the Loess Hilly Region. Res. Soil Water Consev. 2016, 5, 100-105. Available online: http://www.cnki.com.cn/Article/CJFDTotal-STBY201605017.htm (accessed on 19 August 2020).

33. Kou, M.; Jiao, J.Y.; Yin, Q.L.; Du, H.D.; Wang, D.L. Water holding capacity and potential nutrient return capacity of main herb species litter in the Hill-Gully Loess Plateau. Acta Ecol. Sin. 2015, 35, 1337-1349. [CrossRef]

34. Sato, Y.; Kumagai, T.; Kume, A.; Otsuki, K.; Ogawa, S. Experimental analysis of moisture dynamics of litter layers?the effects of rainfall conditions and leaf shapes. Hydrol. Process. 2004, 18, 3007-3018. [CrossRef]

35. Biral, V.C.N.; Will, R.E.; Zou, C.B. Establishment of Quercus marilandica Muenchh. and Juniperus virginiana L. in the Tallgrass Prairie of Oklahoma, USA Increases Litter Inputs and Soil Organic Carbon. Forests 2019, 10, 329. [CrossRef]

36. Santonja, M.; Milcu, A.; Fromin, N.; Rancon, A.; Shihan, A.; Fernandez, C.; Baldy, V.; Hättenschwiler, S. Temporal Shifts in Plant Diversity Effects on Carbon and Nitrogen Dynamics During Litter Decomposition in a Mediterranean Shrubland Exposed to Reduced Precipitation. Ecosystems 2018, 22, 939-954. [CrossRef]

37. Cheng, J.; Jing, G.; Wei, L.; Jing, Z. Long-term grazing exclusion effects on vegetation characteristics, soil properties and bacterial communities in the semi-arid grasslands of China. Ecol. Eng. 2016, 97, 170-178. [CrossRef]

38. Guanghua, J.; Wei, L.; Kailiang, Y.; Zak, R.; Jimin, C. Effects of fertilization, burning, and grazing on plant community in the long-term fenced grasslands. Plant Soil Environ. 2017, 63, 171-176. [CrossRef]

39. Mayer, R.; Kaufmann, R.; Vorhauser, K.; Erschbamer, B. Effects of grazing exclusion on species composition in high-altitude grasslands of the Central Alps. Basic Appl. Ecol. 2009, 10, 447-455. [CrossRef]

40. Shi, X.-M.; Li, X.G.; Li, C.T.; Zhao, Y.; Shang, Z.H.; Ma, Q. Grazing exclusion decreases soil organic C storage at an alpine grassland of the Qinghai-Tibetan Plateau. Ecol. Eng. 2013, 57, 183-187. [CrossRef]

41. Borer, E.T.; Seabloom, E.W.; Gruner, D.S.; Harpole, W.S.; Hillebrand, H.; Lind, E.; Adler, P.B.; Alberti, J.; Anderson, T.M.; Bakker, J.D.; et al. Herbivores and nutrients control grassland plant diversity via light limitation. Nature 2014, 508,517-520. [CrossRef]

42. Van Staalduinen, M.; During, H.; Werger, M.J. Impact of grazing regime on a Mongolian forest steppe. Appl. Veg. Sci. 2007, 10, 299-306. [CrossRef]

43. Van Staalduinen, M.A.; Anten, N.P.R. Differences in the compensatory growth of two co-occurring grass species in relation to water availability. Oecologia 2005, 146, 190-199. [CrossRef]

44. Sasaki, T.; Okayasu, T.; Takeuchi, K.; Jamsran, U.; Jadambaa, S. Patterns of floristic composition under different grazing intensities in Bulgan, South Gobi, Mongolia. Grassl. Sci. 2005, 51, 235-242. [CrossRef]

45. Díaz, S.; Lavorel, S.; McIntyre, S.; Falczuk, V.; Casanoves, F.; Milchunas, D.G.; Skarpe, C.; Rusch, G.M.; Sternberg, M.; Noy-Meir, I.; et al. Plant trait responses to grazing? A global synthesis. Glob. Chang. Boil. 2007, 13, 313-341. [CrossRef]

46. Xiong, S.; Nilsson, C. The effects of plant litter on vegetation: A meta-analysis. J. Ecol. 1999, 87, $984-994$. [CrossRef] 
47. Yan, Y.; Lu, X. Is grazing exclusion effective in restoring vegetation in degraded alpine grasslands in Tibet, China? PeerJ 2015, 3, e1020. [CrossRef] [PubMed]

48. Takatsuki, S.; Sato, M.; Morinaga, Y. Effects of grazing on grassland communities of the forest-steppe of northern Mongolia: A comparison of grazed versus ungrazed places. Grassl. Sci. 2018, 64, 167-174. [CrossRef]

49. Kakinuma, K.; Ozaki, T.; Takatsuki, S.; Chuluun, J. How Pastoralists in Mongolia Perceive Vegetation Changes Caused by Grazing. Nomad Peoples 2008, 12, 67-73. [CrossRef]

50. Ren, H.; Taube, F.; Han, G.; Lan, Z.; Wan, H.; Schönbach, P.; Gierus, M. Grazing effects on herbage nutritive values depend on precipitation and growing season in Inner Mongolian grassland. J. Plant Ecol. 2016, 9 , 712-723. [CrossRef]

51. Wen, L.; Jinlan, W.; Xiaojiao, Z.; Shangli, S.; Wenxia, C. Effect of degradation and rebuilding of artificial grasslands on soil respiration and carbon and nitrogen pools on an alpine meadow of the Qinghai-Tibetan Plateau. Ecol. Eng. 2018, 111, 134-142. [CrossRef]

52. Yao, X.; Wu, J.; Gong, X.; Lang, X.; Wang, C.; Song, S.; Ahmad, A.A. Effects of long term fencing on biomass, coverage, density, biodiversity and nutritional values of vegetation community in an alpine meadow of the Qinghai-Tibet Plateau. Ecol. Eng. 2019, 130, 80-93. [CrossRef]

53. Thurow, T.L.; Blackburn, W.H.; Warren, S.D.; Taylor, C.A. Rainfall Interception by Midgrass, Shortgrass, and Live Oak Mottes. J. Range Manag. 1987, 40, 455-460. [CrossRef]

(C) 2020 by the authors. Licensee MDPI, Basel, Switzerland. This article is an open access article distributed under the terms and conditions of the Creative Commons Attribution (CC BY) license (http://creativecommons.org/licenses/by/4.0/). 